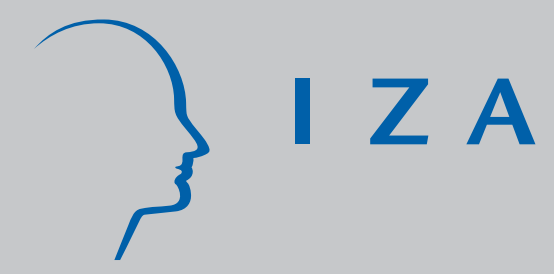

IZA DP No. 3063

Measuring Ethnic Identity and Its Impact on Economic Behavior

Amelie Constant

Klaus F. Zimmermann

September 2007 


\title{
Measuring Ethnic Identity and Its Impact on Economic Behavior
}

\author{
Amelie Constant \\ Georgetown University, DIW DC and IZA \\ Klaus F. Zimmermann \\ IZA, Bonn University and DIW Berlin
}

Discussion Paper No. 3063

September 2007

\author{
IZA \\ P.O. Box 7240 \\ 53072 Bonn \\ Germany \\ Phone: +49-228-3894-0 \\ Fax: +49-228-3894-180 \\ E-mail: iza@iza.org
}

\begin{abstract}
Any opinions expressed here are those of the author(s) and not those of the institute. Research disseminated by IZA may include views on policy, but the institute itself takes no institutional policy positions.

The Institute for the Study of Labor (IZA) in Bonn is a local and virtual international research center and a place of communication between science, politics and business. IZA is an independent nonprofit company supported by Deutsche Post World Net. The center is associated with the University of Bonn and offers a stimulating research environment through its research networks, research support, and visitors and doctoral programs. IZA engages in (i) original and internationally competitive research in all fields of labor economics, (ii) development of policy concepts, and (iii) dissemination of research results and concepts to the interested public.
\end{abstract}

IZA Discussion Papers often represent preliminary work and are circulated to encourage discussion. Citation of such a paper should account for its provisional character. A revised version may be available directly from the author. 
IZA Discussion Paper No. 3063

September 2007

\section{ABSTRACT}

\section{Measuring Ethnic Identity and Its Impact on Economic Behavior ${ }^{*}$}

The paper advocates for a new measure of the ethnic identity of migrants, models its determinants and explores its explanatory power for various types of their economic performance. The ethnosizer, a measure of the intensity of a person's ethnic identity, is constructed from information on the following elements: language, culture, societal interaction, history of migration, and ethnic self-identification. A two-dimensional concept of the ethnosizer classifies migrants into four states: integration, assimilation, separation and marginalization. The ethnosizer largely depends on pre-migration characteristics. Empirical evidence studying economic behavior like work participation, earnings and housing decisions demonstrates the significant relevance of ethnic identity for economic outcomes.

JEL Classification: F22, J15, J16, Z10

Keywords: ethnicity, ethnic identity, acculturation, migrant assimilation, migrant integration, work, cultural economics

Corresponding author:

Klaus F. Zimmermann

IZA

P.O. Box 7240

D-53072 Bonn

Germany

E-mail: zimmermann@iza.org

\footnotetext{
" Contribution to the invited paper session on "Cultural Identity, Ethnicity and Markets" at the 2007 meeting of the European Economic Association in Budapest. Financial support from Volkswagen Foundation for the IZA research program on "The Economics and Persistence of Migrant Ethnicity" is gratefully acknowledged. We thank Liliya Gataullina for able research assistance.
} 


\section{Introduction}

Personal identity is what makes individuals unique and different from others, including the selfdefinition of one's self. ${ }^{1}$ Likewise, ethnic identity is whatever makes individuals the same or different in comparison to other ethnic groups. But, it may also encompass a network of strong beliefs, values, and what people hold dear; it builds and shapes peoples' lives. Ethnic identity surfaces and becomes a strong part of the migrants' persona when they arrive in a host country that is dominated by a different ethnicity, culture, language, etc. Ethnic identity is then like a property that a person can have for some time, can lose it and acquire a new one, or lose it and never take on or assume another one.

It is widely accepted and documented in the economics scholarly literature that ethnicity as well as the racial and ethnic characteristics of migrants affect demographics and have an impact on the growth and development of the host country. Ethnicity, as assigned by birth, usually coincides with economic and social inequality between the dominant and minority groups, with political and social repercussions. On the other hand, ethnicity and ethnic capital are acknowledged to be the impetus of entrepreneurial spirit. The role of culture and ethnic identity on economic outcomes is less acceptable. Recently, there is a growing literature on the effects of culture on economic outcomes. Constant, Gataullina and Zimmermann (2006a) include useful references on ethnic identity from the social sciences and psychology. Guiso, Sapienza, and Zingales (using beliefs about trust) show a pervasive impact of culture in many economic choices (2006). The value of cultural diversity is evidenced in US cities through its net positive effect on the productivity of natives (Ottaviano and Peri 2006). Zimmermann (2007a) and a special issue of the Journal of Population Economics (volume 20, issue 3, 2007) documents the rising interest of economists into the field of ethnicity and identity.

1. The economics of identity has found strong theoretical interest recently, see Kuran (1998), Akerlof and Kranton (2000) and Bénabou and Tirole (2007), for instance. 
Ethnic identity, much like personality ${ }^{2}$ and other individual characteristics, influences labor market outcomes. Constant, Gataullina, and Zimmermann (2006b) find that ethnic identity varies between the sexes and has a significant impact on their working behavior. Darity, Mason, and Stewart (2006) provide a secular theory of racial (or ethnic) identification formation. Their evolutionary game theory model may result in an equilibrium, where all persons follow an individualist identity strategy, another where all persons pursue a racialist (or ethnic) identity strategy, or a mixture of both. Consequently, race or ethnicity may be more or less significant for both market and non-market social interactions. A positive impact of racial identity on economic outcomes, that is, the productivity of social interactions, is the cornerstone of the theory. This also explains the persistence of racial or ethnic privileges in market economies. Fearon and Laitin (2000) argue that ethnic identities are socially constructed, either by individual actions or by supra-individual discourses of ethnicity. They also may take the form of oppositional identities, which imply a rejection of the dominant, typically white behavioral norms (AustenSmith and Fryer, 2005; Battu, Mwale and Zenou, 2007).

Mason (2004) establishes a stable identity formation among Mexican-Americans and other Hispanics. He shows that these ethnicities are able to increase their income substantially through acculturating into a non-Hispanic white racial identity. Bisin, Patacchini, Verdier, and Zenou (2006) find that, in line with their theoretical analysis, identity with and socialization to an ethnic minority are more pronounced in mixed than in segregated neighborhoods. The strength of identification with the majority culture regardless of strength of (ethnic) minority identity is very important for labor market outcomes (Nekby and Rödin 2007). Expanding on the concept of ethnic human capital, Chiswick (2006) shows that economic determinants of "successful" and “disadvantaged” group outcomes are sensitive to the relationship between ethnic and general human capital, especially with regard to externalities in the processes by which they are formed.

2. Recently, personality and behavior traits have been considered as part of the individual human capital, which counts differentially for men and women and for different ethnic groups (Bowles, Gintis, and Osborne 2001). 
In this paper, we summarize and extend previous research on ethnic identity and economic outcomes. Using the German Socio-economic Panel, we test the robustness of the ethnosizer as we contrast it to direct measures of self-identification and estimate it with Poisson regressions. We proceed in the next section by laying the grounds of the theoretical conception of what a migrant's ethnic identity is. In section 3 we quantify and measure the ethnic identity of migrants in Germany. In section 4 we analyze the causality of working hours on ethnic identity. In a simulation exercise in section 5, we evaluate the economic consequences of the ethnosizer, especially on labor force participation, earnings and homeownership. Lastly, we conclude.

\section{A Theory of Ethnic Identity}

We follow the concept of ethnic identity as formulated in the economics of immigration literature by Constant, Gataullina, and Zimmermann (2006a). They perceive ethnic identity to be different than ethnicity, which denotes where people come from, and it is an ascribed status. Ethnic identity becomes pertinent upon arrival in the host country, given that there is a sufficient cultural distance between home and host countries. Ethnic identity is how individuals perceive themselves within an environment as they categorize and compare themselves to others of the same or a different ethnicity. It is the closeness or distance one feels from one’s own ethnicity or from other ethnicities, as one tries to fit into the society. As such, it can differ among migrants of the same origin, or be comparable among migrants of different ethnic backgrounds. We consider the generality of ethnic identity to be one of the most important characteristics of our conception of identity, because it makes it possible to compare migrants within an ethnic group, and to draw parallels between representatives of different ethnicities. As such, ethnic identity is the balance between commitment to, affinity to, or self-identification with the culture, norms, and society of origin and commitment to or self-identification with the host culture and society. We do not restrict ethnic identity, however, to any specific type of relationships between commitment to the origin and commitment to the host country. 
While Constant, Gataullina, and Zimmermann (2006a) focused on ethnic identity related to positive commitments, here, we augment the theoretical possibilities of the formation and manifestation of ethnic identity. The balance of commitments could be stable, but the commitments could turn negative. A complete notion of ethnic identity, thus, includes the extreme cases of "subvert", negative or undermining revealment of the ethnic identity of migrants. We conjecture that a migrant who arrives in the host country moves along a plane formed by two axes representing commitment to the home and host countries. On the horizontal axis we measure commitment to and self-identification with the country of origin, and on the vertical axis we measure commitment to and self-identification with the host country. As we allow for the trade-off between commitment to one or the other country in any possible combination, the formed plane has four quadrants.

In Figure 1 we illustrate our theoretical model of a complete multidimensional ethnic identity. A migrant who is at point $(0,0)$ has lost all ethnic identity related to the country of origin. Moving to the right along the positive part of the horizontal axis (or in the north-east quadrant) is an indication of ethnic retention and increasing commitment to the country of origin. A migrant reaches the maximum commitment to the culture of origin at point $(1,0)$, that is, he or she totally identifies with the culture of origin and not at all with the host country. At point $(1,0)$, migrants are 'ethnic', because they did not alter their ethnic identity and affinity with the country of origin after they migrated and changed country of residence. A migrant can also move beyond point $(1,0)$, as he or she identifies more fanatically with the country of origin. This could be the case where individuals become radical and practice more extreme views than comparable co-ethnics who stay in the home country. We allow migrants to also move to the left of point $(0,0)$ along the negative part of the horizontal vector. This is the case of disgruntled individuals who turn against their own heritage and culture, while they can commit to and identify with the host country if they are in the north-west quadrant. Figure 1 depicts the complete theoretical possibilities of positive, fanatical, and subvert ethnic identity. 
Self-identification with the host country's culture and beliefs is indicated by the vertical axis. Starting at the origin of the Cartesian coordinates, a migrant at point $(0,0)$ exhibits no identification with the host country whatsoever. This is a person with no ethnic identity and no commitment to any country. A migrant who moves up from $(0,0)$ to $(0,1)$ on the positive vector of the vertical axis, expresses increasing similarity and identification with it. We assume that migrants who are at this coordinate, $(0,1)$, achieve an ethnic identification that is similar to that of natives. That is, they reach a full adaptation of the culture and beliefs of the host country. Implicitly, this point captures the idea of migrant assimilation or acculturation in economic research. It is possible that migrants can move beyond point $(0,1)$ (the maximum of selfidentification with the host country). This is the case of overzealous migrants, who over-identify with the host country (more than comparable natives).

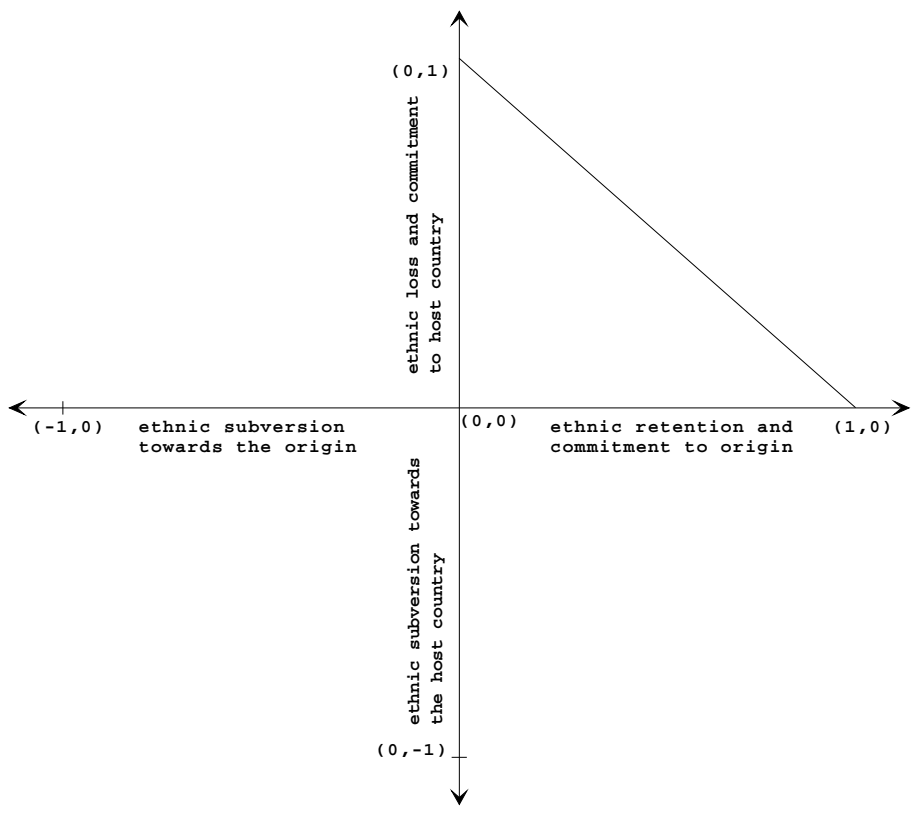

Figure 1. Complete illustration of ethnic identity; retention, relinquishment, and subversion

In contrast, migrants can also be malcontent with the host country's culture, actively oppose it and develop a subvert self-identification towards it. The movement on the negative vector of the vertical axis portrays this possibility. Note that, when migrants move along the 
negative part of the vertical axis, they can be either in the south-east or the south-west quadrant. The south-east quadrant exemplifies individuals who keep the ethnic identity of the home country, but turn against the host country. While being in the south-west quadrant is a valid theoretical possibility of individuals turning against both countries, it is rather unlikely to happen in the real world (if we assume rational and mentally sound individuals). We continue our analysis of ethnic identity focusing on the north-east quadrant.

In reality, individuals may exhibit strong association with, commitment to, and malcontent to either or both the culture of ancestry and the host culture. The two-dimensional model of the measurement of ethnic identity suggests that commitments to two different societies can coexist and influence each other in several ways. In other words, the level of dedication to the origin does not preclude the degree of the commitment to the host society. This assumption recognizes that a migrant, who strongly identifies with the culture and values of his or her ancestry, may or may not have a strong involvement with the dominant culture. Similarly, a migrant with a strong affinity to the values and beliefs of the host country may or may not totally identify with the culture of ancestry. At the same time, migrants may also be completely detached from the home or host country. The two-dimensional ethnosizer of Constant, Gataullina, and Zimmermann (2006a) allows for this case as well.

Looking at the positive quadrant (north-east) and assuming for simplicity that, at any time, the commitments to the home and host countries are linearly dependent and mutually exclusive and they sum up to one, then the more an individual commits to and feels for one country the less he or she commits to and feels for the other country. For example, the more migrants become similar to natives, the more they relinquish and abandon their own culture. This linear representation is a special (and rather restrictive) case of the concept of ethnic identity, and depicted in Figure 1 by a movement along the diagonal $(1,0)$ to $(0,1)$. We call this measurement of ethnic identity, the one-dimensional ethnosizer. 
Confronted with both cultures, which combination of commitments do migrants choose to uphold? The two-dimensional ethnosizer of Figure 2 answers this question and shows where exactly migrants are in the positive quadrant. As illustrated in Figure 2, the ethnosizer contains four measures or regimes of ethnic identity differentiated by the strength of cultural and social commitments. Quadrants A, I, M, and S correspond to: Assimilation (A), a strong identification with the host culture and society, coupled with a firm conformity to the norms, values, and codes of conduct, and a weak identification with the ancestry; Integration (I), achieved when an individual combines, incorporates, and exhibits both strong dedication to the origin and commitment and conformity to the host society; Marginalization (M), a weak dedication to or strong detachment from either the dominant culture or the culture of origin; and, Separation (S), an exclusive commitment to the culture of origin even after years of emigration, paired with weak involvement in the host culture and country realities. Starting at point $(1,0)$, a migrant can undergo a more complicated journey through the various states, leaving separation towards integration, assimilation or marginalization, or remaining separated.

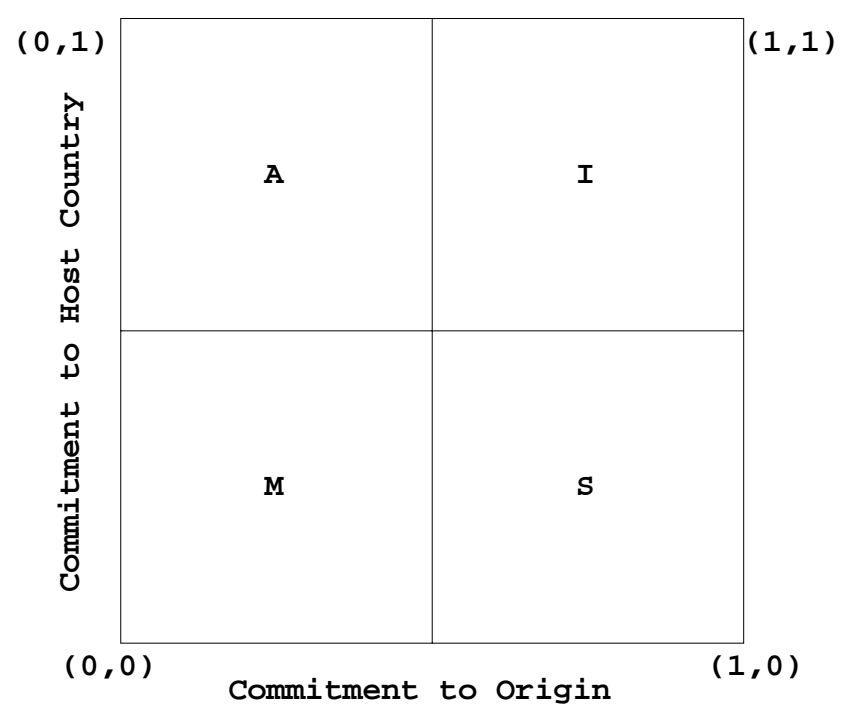

Figure 2. The two-dimensional non-negative ethnosizer 


\section{Ethnosizing Migrants}

To ethnosize the ethnic identity of migrants we follow Constant, Gataullina, and Zimmermann (2006a), who apply a combination of key elements that epitomize ethnic identity. In their attempt to quantify ethnic identity they use data from the German Socio-Economic Panel (GSOEP), a nationally representative survey collected annually since 1984 by the German Institute of Economic Research (DIW Berlin). The GSOEP focuses on migrants of the guestworker population, namely those who arrived from Turkey, Greece, Italy, Spain and the former Yugoslavia. They constitute the majority of the migrant population in Germany. The 2000, 2001 and 2002 waves of GSOEP contain the most relevant information on the respondents' ethnic identity. This is why we limit our analysis to those respondents who participated in these waves. The sample is also restricted to males and females aged 18-65 (with the upper limit corresponding to the official retirement age in Germany), whose nationality is not German, who were not born in Germany, and who were not in school at the time of the survey. This leaves us with samples of a typical size of about 1,200 migrants, where the precise number depends on the number of completed answers to the concrete questions under study.

To construct the four measures of the two-dimensional ethnosizer empirically, we identify pairs of questions in the GSOEP survey, which transmit information on personal devotion and commitment to both the German culture and society and to the culture and society of origin with respect to five key elements: (i) language; (ii) visible cultural elements; (iii) ethnic self-identification; (iv) ethnic networks; and (v) future citizenship plans. The GSOEP documents how well the respondents speak German and the language of origin, what are the origins of their preferred food, media and music, how strong is their self-identification with Germany and with the country of origin, what are the origins of their closest friends, and finally, what are their future citizenship and residency plans. For example, we classify migrants with a "very good” or "good" command of both the German and the language of origin as linguistically integrated. Migrants with a good command of German and little or no command of the language of origin 
are considered linguistically assimilated; migrants with "very good” or "good" command of the language of origin and little or no command of German are labelled linguistically separated; and migrants with a "bad” command of both languages are classified as linguistically marginalized. We classify migrants with respect to their cultural preferences, ethnic self-identification, ethnic networking, and citizenship plans in a similar fashion.

This classification method demonstrates that despite the common belief in anthropology, sociology and psychology it is practically impossible to determine the overall balance of migrants' commitments. For example, linguistic and cultural integration does not guarantee integration with respect to self-identification or ethnic networking. Likewise, a migrant may have excellent command of German and the language of origin, but may still strongly identify only with the home country and have friends only of the same origin. To judge the individuals' general devotion to the culture and society of home and host countries across the five elements of ethnic identity, we generate four scores for each possible combination of commitments: Integration is the number of times that each respondent is identified as 'integrated' in the five aspects of ethnic identity, assimilation is the number of times that each respondent is identified as 'assimilated', separation is the number of times that a respondent is identified as 'separated', and marginalization is the number of times a migrant is identified as marginalized in the five aspects of ethnic identity.

These four measures or regimes of the ethnosizer are used to characterize the combination of socio-cultural commitments of each respondent in the sample. Each of them can take a value between zero and five, and add up to five for each individual. For example, migrants who score four in separation, one in integration, zero in assimilation, and zero in marginalization reveal a clear preference. Migrants who score two in integration, two in separation, one in assimilation, and zero in marginalization, do not demonstrate a clear preference in their sociocultural commitments. 
To what extent does the ethnosizer differ from the direct measure of ethnic selfidentification $^{3}$ provided by the survey? The self-identification question is subjective, and hence open to debate. We, therefore, seek to balance the responses by more objective 'indirect' measures of ethnic identity. The ethnosizer is basically such an attempt, and provides equal weights to the five elements. The direct measure of ethnic self-identification can be decomposed in four $(0,1)$-dummy variables reflecting the four ethnosizer regimes. This variable classifies each individual clearly into one regime. The ethnosizer system of indicators, however, classifies each individual five times (including the direct measure of ethnic self-identification), and potentially different in four cases than by the self-evaluation alone.

Table 1 uses GSOEP data optimized for the purpose of comparison of the ethnosizer with the direct measure of ethnic self-identification. We observe 1,339 individuals and generate 6,695 observations that are cross-classified according to the four regimes (integration, assimilation, separation and marginalization). The cells on the main diagonal of the contingency table contain the cases where self-classification coincides with the judgement of the ethnosizer. The agreement is, in general, small: $45.9 \%$ for integration, $53.6 \%$ for assimilation, $54.9 \%$ for separation and 31.9\% for marginalization (percentages from the column totals). From those who consider themselves to be marginalized, in $23.7 \%$ of the cases we find evidence of integration. In $32.5 \%$ of the cases for those who self-report integration, we find evidence of assimilation. Selfclassified assimilation goes with $12.6 \%$ cases of marginalization, and self-reported separation coincides with $21 \%$ cases of integration. This provides support for the attempt to balance the self-evaluation question out through the ethnosizer.

3. See Zimmermann, Zimmermann, and Constant (2007) and Zimmermann, Gataullina, Constant, and Zimmermann (2006) for an econometric analysis of ethnic self-identification using GSOEP data. 


\section{Work Intensity and the Ethnosizer}

Using the ethnosizer and data from the German Socio-economic Panel, Constant, Gataullina, and Zimmermann (2006a) investigate the relationship of the one- and two-dimensional ethnosizers to age, age at entry, religion, educational levels, and ethnic origins. In the two-dimensional ethnosizer, young migrants are integrated or assimilated the best. Women are only different than men in their assimilation scores, meaning that they assimilate or become alike to Germans less than men. When it comes to integration, that is, keeping and valuing both cultures, religion is on the way. ${ }^{4}$ Muslims, Catholics, and other religions do not integrate, but Catholics and other Christians assimilate well. Muslim migrants also score high on marginalization in comparison to non religious individuals followed by the Christians. Migrants with college degree or higher education in the home country integrate well, but they do not assimilate. School education, whether complete or incomplete, is more harmful for the process of integration or assimilation than no education in the home country. Likewise, vocational training leads to less assimilation and more separation. The ethnicity of the individuals, measured by dummy variables of the countries of origin, remains statistically different from zero with an interesting pattern. ExYugoslavs assimilate more and separate less than Turks, but they also marginalize more. While Spaniards and Italians are no different than Turks, Greeks integrate less and marginalize more.

In principle, migrants enter a host country with a strong ethnic commitment to their own origin and a lower attachment to the majority ethnicity. Depending on the planned duration of the move, and in interaction with investment in human capital, participation in the labor market and the degree of family formation, ethnic identity, and hence the ethnosizer, will evolve. If the ethnosizer will change across the tenure in the host country together with those factors, then they are potentially highly correlated and could be misleading regressors in an ethnosizer equation. Using direct measures of ethnic self-identification towards the own origin and to the host 
country, Zimmermann, Gataullina, Constant, and Zimmermann (2006) find that human capital acquired in the host country does not affect the attachment and affinity to the receiving country. Clearly, pre-migration characteristics dominate ethnic self-identification. In particular, human capital acquired in the home country leads to lower identification with the host country for males and females, while males only have a higher affiliation with the original ethnicity and culture. However, Aspachs-Bracons, Clots-Figueras, Costa-Font, and Masella (2007) have shown that compulsory language policy implemented in Catalonia have an effect on identity.

While Constant, Gataullina, and Zimmermann (2006a) had excluded human capital acquired in the host country and labor market integration in their analysis of the ethnosizer, we examine the potential of these post-migration characteristics for identity-formation. We argue that while ethnic identity should affect work participation and cultural activities like human capital formation, the ethnic identity of those working should not be influenced by work intensity and education from the receiving country. In the sequel, we will examine this by concentrating on a sample of working men.

Table 2 contains the descriptive statistics of our sample of migrants. There are 1,195 individuals in total, 658 are working (and have observed working hours), and 406 are working men. It is obvious that those working have larger ethnosizer measures for integration and assimilation, but lower ethnosizer values for marginalization and separation. Working men are younger and they were also younger at the time of entry into Germany, there are more Muslim, less Catholic, more individuals with no education in the country of origin, who are better educated in Germany than individuals in the total sample.

Since the four ethnosizer measures can take count values from zero to five, we have estimated robust Poisson regressions using a larger number of pre- and post-migration characteristics as determinants. The robust specification using the so-called sandwich estimator of the covariance matrix avoids a potential bias in the usual standard errors caused by possible dispersion. The reference group consists of non-religious Turks, with no education in the home 
country and primary or lower secondary education in Germany. Results of the parameter estimates of our new analysis are contained in Table 3. They imply that Muslims are less integrated and more marginalized, while Catholics integrate better. Educational activities in the home country like college attendance, vocational training and complete school lead to a lower level of assimilation and a higher likelihood of separation. Greeks integrate less and marginalization is strongly affected by age. Education in Germany is insignificant, with the exception of a negative effect of a university degree in Germany on separation.

We have included hours worked as a measure of labor market integration. Migrant men typically work when they have a legal right to do so, or they are restricted by involuntary unemployment. They actually work within a wide span between 2 and 80 hours per week, and have mean weekly working hours of 42 with a standard deviation of 8 hours. Working hours are distributed like follows: $30 \%$ of the migrant men work 40 hours per week, 33\% work less and 37\% work more. We find here that hours worked does not affect the measures of the ethnosizer. The tests for exogeneity that we have undertaken have not shown evidence that hours worked is endogenous. We can conclude that we obtain no evidence that work intensity has an effect on ethnic identity.

These findings confirm previous literature. A successful immigration policy that aims at a decent integration and assimilation has to rely largely on entry selection and not on education in the host country, with the exception of German university education. Former foreign students with a university degree could get easier legal access to the German labor market, and migrants should be young at first entry. Education from the country of origin is typically a burden for adjustments.

\section{The Economic Consequences of Ethnicity}

In the previous sections we summarized some efforts that have been made to define, measure and explain ethnic identity. We now compare recent findings about the effects of ethnic identity 
on economic behavior. Constant, Gataullina, and Zimmermann (2006b) deal with the probability to work, Zimmermann (2007b) with earnings, and Constant, Roberts and Zimmermann (2007) with homeownership. All three papers use the GSOEP data, as discussed above in section 3, and employ Probit (work probability, homeownership) and Tobit models (earnings), where the twodimensional ethnosizer is added to standard regressions to examine the particular contribution of ethnic identity. Consistently, it is found that ethnicity matters significantly and that the findings are very robust with respect to the concrete model specification. To put it differently: The inclusion of the ethnosizer does not change the parameter estimates of the standard variables in any relevant way. Nevertheless, the parameter estimates of the ethnicity effects have a strong impact on economic behavior.

Table 4 summarizes the findings. In the probability to work and earnings analyses there are separate estimates for both genders. In the case of the housing or homeowner decision the focus is on female and male household heads together. The entry in each cell of a column should be understood as a simulated absolute change of the observed percentage (work, homeownership) or a percentage change in income if the listed ethnosizer is set at the theoretical maximum (equal to five) and the remaining three measures are at their theoretical minimum (equal to zero). While such changes are unrealistic in practice, they are substantial, and the simulation exercise provides a clear picture of the relative importance of the ethnic identity factors.

Following Constant, Gataullina, and Zimmermann (2006b), the first two columns of Table 4 deal with the probability to work for males and females. In their particular sample, 74\% of the sampled migrant men and $46 \%$ of the sampled migrant women worked at the time of the survey. If all men were fully assimilated, this would result in a $12 \%$ increase, or a jump to an $86 \%$ probability to work among migrant males. In the case of integration, the rise would be somewhat smaller, only $82 \%$. Thus, integration is not as sizable as assimilation for men, although the difference in estimation is not statistically different. Complete separation leads to a 
drop in work probability by $6 \%$, or a decrease to $68 \%$ among men. Finally, if all male migrants were marginalized, their working rate would drop to 54\%, and thus, become somewhat closer to the actual probability to work of the sampled migrant women. Integration for females functions quite differently. Unlike the male effects integration matters very much, while the effect of assimilation is close to zero. If all females were integrated, their probability to work would increase by $20 \%$, to $66 \%$, and hence become about the same as the probability to work for males if they would be fully separated. For assimilation, the female work probability would drop down to $45 \%$. For separation and marginalization it would decrease to $38 \%$, although the difference in estimation is not statistically different.

A further issue is earnings: In the sample of Zimmermann (2007b) the average monthly labor earnings of the sampled male migrants are 3,492 Euros, while the average monthly labor earnings of the sampled female migrants are 1,175 Euros. If all male migrants were fully integrated (or fully assimilated), their earnings would grow dramatically by $157 \%$ (or $119 \%$ ) to 5,493 Euros (or 4,170 Euros) a month. Full separation of male migrants would lead to a reduction in monthly earnings to 853 Euros, and full marginalization would decrease the average monthly earnings of male migrants below subsistence level to 271 Euros. If all female migrants were fully integrated their earnings would increase to 4,290 Euros a month, a much higher amount than that for males in the sample. Total assimilation, separation or marginalization of female migrants, however, would lead to a decrease in labor earnings to about 1,147 Euros, 414 Euros or 38 Euros, respectively. These numbers are substantial, indicating in particular the advantage of integration above assimilation. The disadvantage of marginalization in comparison with separation.

Simulation on the probability of homeownership using the coefficients from an estimated Probit model, Constant, Roberts, and Zimmermann (2007) illustrate that if all migrants were assimilated, $55 \%$ would be homeowners. This is more than double the actual $20 \%$ homeownership rate in their sample. Similarly, if all migrants were integrated, $46 \%$ would own 
their own homes. Although, being all marginalized is not statistically different from being all separated, the rates are economically different, namely $12 \%$ for marginalization and $3 \%$ for separation. This implies that it is the lack of attachment to the host country, rather than continuing ties to the origin country, that contribute to poor homeownership outcomes.

\section{Conclusions}

A fast growing literature in economics deals with ethnic identity. We offer a complete concept of ethnic identity and advertise in this paper for a new empirical modeling concept. Theoretically, we allow migrants to retain their own culture and ethnic identity, to renounce it and totally identify with the host country, to appreciate and cherish both cultures, and to even subvert their own or the host country's ethnic identity. The ethnosizer, a tangible measure of ethnic identity, is constructed from individual information on language, culture, societal interaction, history of migration, and ethnic self-identification. Bypassing the one-dimensional ethnosizer, the twodimensional variant classifies migrants into four regimes: integration, assimilation, separation and marginalization. Empirical evidence provided for male migrant workers suggests that the ethnosizer differs significantly from the direct individual ethnic self-identification measure, and depends largely on pre-migration characteristics. Muslims are less integrated and more marginalized, while Catholics integrate better. Educational activities in the home country like college attendance, vocational training and complete school lead to a lower level of assimilation and a higher likelihood of separation. Greeks integrate less and marginalization is strongly affected by age. Education in Germany is insignificant, with the exception of a negative effect of a university degree in Germany on separation. Work intensity does not affect the four ethnosizer measures. Empirical evidence studying economic behavior like work participation, earnings and housing decisions demonstrates the significant relevance of ethnic identity for economic outcomes. 


\section{References}

Akerlof, George A., and Rachel E. Kranton (2000). "Economics and Identity." Quarterly Journal of Economics, 115, 715-753.

Aspachs-Bracons, Oriol, Irma Clots-Figueras, Joan Costa-Font, and Paolo Masella (2007). "Compulsory Language Educational Policies and Identity Formation." mimeo.

Austen-Smith, David, and Roland G. Fryer Jr. (2005). “An Economic Analysis of 'Acting White'.” Quarterly Journal of Economics, 120, 551-583.

Battu, Harminder, McDonald Mwale, and Yves Zenou (2007). "Oppositional Identities and the Labor Market." Journal of Population Economics, 20, 643-667.

Bénabou, Roland, and Jean Tirole (2007). “Identity, Dignity and Taboos: Beliefs as Assets.” IZA Discussion Paper No. 2583.

Bisin, Alberto, Eleonora Patacchini, Thierry Verdier, and Yves Zenou (2006). “'Bend it like Beckham’: Identity, Socialization and Assimilation.” CEPR Discussion Paper No. 5662.

Bisin, Alberto, Eleonora Patacchini, Thierry Verdier and Yves Zenou (2007). "Are Muslim Immigrants Different in Terms of Cultural Integration?" mimeo.

Bowles, Samuel, Herbert Gintis, and Melissa Osborne (2001). "Incentive-Enhancing Preferences: Personality, Behavior, and Earnings.” The American Economic Review, 91, 2, 155-158.

Chiswick, Carmel U. (2006) “The Economic Determinants of Ethnic Assimilation.” IZA Discussion Paper No. 2212.

Constant, Amelie, Liliya Gataullina, and Klaus F. Zimmermann (2006a). "Ethnosizing Immigrants.” IZA Discussion Paper No. 2040.

Constant, Amelie, Liliya Gataullina, and Klaus F. Zimmermann (2006b). "Gender, Ethnic Identity and Work.” IZA Discussion Paper No. 2420.

Constant, Amelie, Liliya Gataullina, Laura Zimmermann, and Klaus F. Zimmermann (2006). "Clash of Cultures: Muslims and Christians in the Ethnosizing Process." IZA Discussion Paper No. 2350.

Constant, Amelie, Rowan Roberts, and Klaus F. Zimmermann (2007). "Ethnic Identity and Immigrant Homeownership.” IZA Discussion Paper No. 3050.

Darity, William A., Patrick L. Mason, and James B. Stewart (2006). “The Economics of Identity: The Origin and Persistence of Racial Identity Norms.” Journal of Economic Behavior and Organization, 60, 283-305.

Fearon, James D., and David D. Laitin (2000). "Violence and the Social Construction of Ethnic Identity.” International Organization, 54, 845-877.

Guiso, Luigi, Paola Sapienza, and Luigi Zingales (2006). "Does Culture Affect Economic Outcomes?” NBER Working Paper No. 11999. 
Kuran, Timur (1998). "Ethnic Norms and their Transformation Through Reputational Cascades.” Journal of Legal Studies, 27, 623-659.

Mason, Patrick L., (2004). “Annual Income, Hourly Wages, and Identity among MexicanAmericans and other Latinos.” Industrial Relations, 43, 817-834.

Negby, Lena and Magnus Rödin (2007). “Acculturation Identity and Labor Market Outcomes.” IZA Discussion Paper No. 2826.

Ottaviano, Gianmarco I.P., and Giovanni Peri (2006). "The Economic Value of Cultural Diversity: Evidence from US Cities.” Journal of Economic Geography, 6, 1, 9-44.

Zimmermann, Klaus F. (2007a). “The Economics of Migrant Ethnicity.” Journal of Population Economics, 20, 487-494.

Zimmermann, Klaus F. (2007b). "Migrant Ethnic Identity: Concept and Policy Implications." The Cyprus Economic Society Annual Lecture in Economics 2007. IZA Discussion Paper No. 3056.

Zimmermann, Laura, Liliya Gataullina, Amelie Constant, and Klaus F. Zimmermann (2006). "Human Capital and Ethnic Self-identification of Migrants." IZA Discussion Paper No. 2300. In print 2007: Economics Letters.

Zimmermann, Laura, Klaus F. Zimmermann, and Amelie Constant (2007). "Ethnic Selfidentification of First-generation Immigrants.” International Migration Review, 41, 769-781. 


\section{TABLE 1. Direct Measure of Ethnic Self-identification and the Ethnosizer}

\begin{tabular}{lccccc}
\hline \hline & \multicolumn{5}{c}{ Self-Identification } \\
\cline { 2 - 6 } Ethnosizer & Integration & Assimilation & Separation & Marginalization & Total \\
\cline { 2 - 6 } Integration & $\mathbf{2 0 2}$ & $\mathbf{2 1 9}$ & $\mathbf{7 2 9}$ & $\mathbf{4 4 4}$ & $\mathbf{1 , 5 9 4}$ \\
& 45.91 & 24.07 & 20.98 & 23.74 & \\
& 3.02 & 3.27 & 10.89 & 6.63 & 23.81 \\
Assimilation & $\mathbf{1 4 3}$ & $\mathbf{4 8 8}$ & $\mathbf{4 3 5}$ & $\mathbf{3 7 8}$ & $\mathbf{1 , 4 4 4}$ \\
& 32.50 & 53.62 & 12.52 & 20.21 & \\
& 2.14 & 7.29 & 6.50 & 5.65 & 21.58 \\
Separation & $\mathbf{6 2}$ & $\mathbf{8 8}$ & $\mathbf{1 , 9 0 8}$ & $\mathbf{4 5 1}$ & $\mathbf{2 5 0 9}$ \\
& 14.09 & 9.67 & 54.90 & 24.12 & \\
Marginalization & 0.93 & 1.31 & 28.50 & 6.74 & 37.48 \\
& $\mathbf{3 3}$ & $\mathbf{1 1 5}$ & $\mathbf{4 0 3}$ & $\mathbf{5 9 7}$ & $\mathbf{1 , 1 4 8}$ \\
Total & 7.50 & 12.64 & 11.60 & 31.93 & 17.15 \\
& 0.49 & 1.72 & 6.02 & 8.92 & $\mathbf{6 , 6 9 5}$ \\
& $\mathbf{4 4 0}$ & $\mathbf{9 1 0}$ & $\mathbf{3 , 4 7 5}$ & $\mathbf{1 , 8 7 0}$ & \\
& 100.00 & 100.00 & 100.00 & 100.00 & 100.00 \\
\hline
\end{tabular}

Note: Own calculations on the basis of the GSOEP. Number of individuals: 1,339. Bold numbers are cell counts, followed by percentages of the column totals (italic) and the relative frequencies of the total sample size. 
TABLE 2. Descriptive Statistics

\begin{tabular}{|c|c|c|c|c|c|c|}
\hline & \multicolumn{2}{|c|}{ All respondents } & \multicolumn{2}{|c|}{ Working respondents } & \multicolumn{2}{|c|}{ Working men } \\
\hline & Mean & St.Dev. & Mean & St.Dev. & Mean & St.Dev. \\
\hline \multicolumn{7}{|l|}{ Ethnosizer } \\
\hline Integration & 1.188 & 0.997 & 1.386 & 1.002 & 1.352 & 0.985 \\
\hline Assimilation & 1.063 & 1.065 & 1.199 & 1.086 & 1.219 & 1.128 \\
\hline Separation & 1.902 & 1.397 & 1.676 & 1.326 & 1.695 & 1.320 \\
\hline Marginalization & 0.846 & 0.879 & 0.739 & 0.801 & 0.734 & 0.803 \\
\hline Female & 0.488 & 0.500 & 0.383 & 0.486 & & \\
\hline \multicolumn{7}{|l|}{ Pre-migration characteristics } \\
\hline Age at entry & 22.552 & 11.113 & 20.129 & 10.072 & 19.603 & 10.130 \\
\hline Muslim & 0.351 & 0.477 & 0.305 & 0.461 & 0.360 & 0.480 \\
\hline Catholic & 0.295 & 0.456 & 0.318 & 0.466 & 0.276 & 0.447 \\
\hline Other Christian & 0.275 & 0.447 & 0.302 & 0.460 & 0.276 & 0.447 \\
\hline Other religions & 0.035 & 0.184 & 0.036 & 0.188 & 0.042 & 0.201 \\
\hline Non religious & 0.044 & 0.206 & 0.038 & 0.191 & 0.047 & 0.211 \\
\hline College in home country & 0.060 & 0.238 & 0.061 & 0.239 & 0.067 & 0.249 \\
\hline Vocational training in home country & 0.276 & 0.447 & 0.289 & 0.454 & 0.261 & 0.440 \\
\hline Complete school in home country & 0.254 & 0.435 & 0.248 & 0.432 & 0.259 & 0.438 \\
\hline Incomplete school in home country & 0.159 & 0.366 & 0.109 & 0.312 & 0.081 & 0.274 \\
\hline No education in home country & 0.251 & 0.434 & 0.293 & 0.456 & 0.333 & 0.472 \\
\hline Turkish & 0.358 & 0.479 & 0.319 & 0.467 & 0.372 & 0.484 \\
\hline Ex-Yugoslavian & 0.178 & 0.383 & 0.184 & 0.388 & 0.163 & 0.369 \\
\hline Greek & 0.081 & 0.273 & 0.087 & 0.282 & 0.079 & 0.270 \\
\hline Italian & 0.142 & 0.349 & 0.149 & 0.356 & 0.153 & 0.360 \\
\hline Spanish & 0.038 & 0.192 & 0.047 & 0.212 & 0.047 & 0.211 \\
\hline Other ethnicities & 0.203 & 0.402 & 0.214 & 0.411 & 0.187 & 0.391 \\
\hline \multicolumn{7}{|l|}{ Post-migration characteristics } \\
\hline Age & 45.036 & 13.715 & 42.125 & 10.818 & 41.975 & 10.953 \\
\hline No degree in Germany & 0.197 & 0.398 & 0.134 & 0.341 & 0.108 & 0.311 \\
\hline $\begin{array}{l}\text { Primary/ lower secondary in } \\
\text { Germany }\end{array}$ & 0.212 & 0.409 & 0.254 & 0.436 & 0.296 & 0.457 \\
\hline Higher degree in Germany & 0.507 & 0.500 & 0.521 & 0.500 & 0.498 & 0.501 \\
\hline University degree in Germany & 0.084 & 0.277 & 0.091 & 0.288 & 0.099 & 0.298 \\
\hline Hours worked & 20.657 & 20.834 & 37.578 & 12.381 & 42.065 & 8.843 \\
\hline Number of observations & \multicolumn{2}{|c|}{1,195} & \multicolumn{2}{|c|}{658} & \multicolumn{2}{|c|}{406} \\
\hline
\end{tabular}

Note: Own calculations on the basis of the GSOEP. 
TABLE 3. Robust Poisson Models of the Ethnosizer for Working Men

\begin{tabular}{|c|c|c|c|c|}
\hline Variables & Integration & Assimilation & Separation & Marginalization \\
\hline Constant & $\begin{array}{l}1.474 \\
(1.27)\end{array}$ & $\begin{array}{l}1.003 \\
(1.73)\end{array}$ & $\begin{array}{l}1.384 \\
(1.62)\end{array}$ & $\begin{array}{c}-10.672 * \\
(3.29)\end{array}$ \\
\hline \multicolumn{5}{|l|}{ Pre-migration characteristics } \\
\hline Age at entry & $\begin{array}{l}-0.011 \\
(0.01)\end{array}$ & $\begin{array}{c}-0.051^{*} \\
(0.02)\end{array}$ & $\begin{array}{c}0.044^{*} \\
(0.02)\end{array}$ & $\begin{array}{c}0.036^{*} \\
(0.02)\end{array}$ \\
\hline Age at entry squared & $\begin{array}{c}-0.0001 \\
(0.0003)\end{array}$ & $\begin{array}{c}0.001^{*} \\
(0.0003)\end{array}$ & $\begin{array}{c}-0.0003 \\
(0.0003)\end{array}$ & $\begin{array}{c}-0.001 \\
(0.0004)\end{array}$ \\
\hline Muslim & $\begin{array}{c}-0.317^{*} \\
(0.19)\end{array}$ & $\begin{array}{l}0.252 \\
(0.23)\end{array}$ & $\begin{array}{c}-0.084 \\
(0.19)\end{array}$ & $\begin{array}{l}0.606 * \\
(0.35)\end{array}$ \\
\hline Catholic & $\begin{array}{l}-0.261 \\
(0.18)\end{array}$ & $\begin{array}{c}0.362 * \\
(0.21)\end{array}$ & $\begin{array}{l}-0.162 \\
(0.20)\end{array}$ & $\begin{array}{l}0.300 \\
(0.37)\end{array}$ \\
\hline Other Christian & $\begin{array}{l}-0.104 \\
(0.18)\end{array}$ & $\begin{array}{l}0.129 \\
(0.22)\end{array}$ & $\begin{array}{l}-0.146 \\
(0.20)\end{array}$ & $\begin{array}{l}0.504 \\
(0.35)\end{array}$ \\
\hline Other religions & $\begin{array}{l}-0.205 \\
(0.19)\end{array}$ & $\begin{array}{l}-0.077 \\
(0.25)\end{array}$ & $\begin{array}{l}-0.001 \\
(0.24)\end{array}$ & $\begin{array}{l}0.754^{*} \\
(0.41)\end{array}$ \\
\hline College in home country & $\begin{array}{l}0.073 \\
(0.18)\end{array}$ & $\begin{array}{c}-0.435^{*} \\
(0.25)\end{array}$ & $\begin{array}{l}0.486^{*} \\
(0.21)\end{array}$ & $\begin{array}{l}0.027 \\
(0.30)\end{array}$ \\
\hline Vocational training in home country & $\begin{array}{l}-0.108 \\
(0.15)\end{array}$ & $\begin{array}{c}-0.344^{*} \\
(0.18)\end{array}$ & $\begin{array}{l}0.307^{*} \\
(0.15)\end{array}$ & $\begin{array}{l}0.168 \\
(0.22)\end{array}$ \\
\hline Complete school in home country & $\begin{array}{l}-0.180 \\
(0.14)\end{array}$ & $\begin{array}{c}-0.504^{*} \\
(0.18)\end{array}$ & $\begin{array}{l}0.486^{*} \\
(0.15)\end{array}$ & $\begin{array}{l}0.170 \\
(0.22)\end{array}$ \\
\hline Incomplete school in home country & $\begin{array}{l}-0.155 \\
(0.23)\end{array}$ & $\begin{array}{l}-0.016 \\
(0.26)\end{array}$ & $\begin{array}{l}0.094 \\
(0.19)\end{array}$ & $\begin{array}{l}0.264 \\
(0.25)\end{array}$ \\
\hline Ex-Yugoslavian & $\begin{array}{l}0.004 \\
(0.11)\end{array}$ & $\begin{array}{l}0.076 \\
(0.16)\end{array}$ & $\begin{array}{l}-0.103 \\
(0.11)\end{array}$ & $\begin{array}{l}0.282 \\
(0.18)\end{array}$ \\
\hline Greek & $\begin{array}{c}-0.307^{*} \\
(0.15)\end{array}$ & $\begin{array}{l}0.073 \\
(0.19)\end{array}$ & $\begin{array}{l}0.024 \\
(0.16)\end{array}$ & $\begin{array}{l}0.348 \\
(0.24)\end{array}$ \\
\hline Italian & $\begin{array}{l}-0.207 \\
(0.15)\end{array}$ & $\begin{array}{l}0.027 \\
(0.19)\end{array}$ & $\begin{array}{l}0.144 \\
(0.14)\end{array}$ & $\begin{array}{l}0.194 \\
(0.24)\end{array}$ \\
\hline Spanish & $\begin{array}{l}-0.108 \\
(0.22)\end{array}$ & $\begin{array}{l}-0.188 \\
(0.27)\end{array}$ & $\begin{array}{l}0.191 \\
(0.22)\end{array}$ & $\begin{array}{l}0.248 \\
(0.27)\end{array}$ \\
\hline Other ethnicities & $\begin{array}{l}-0.006 \\
(0.12)\end{array}$ & $\begin{array}{c}0.802 * \\
(0.16)\end{array}$ & $\begin{array}{c}-0.621^{*} \\
(0.15)\end{array}$ & $\begin{array}{l}0.161 \\
(0.20)\end{array}$ \\
\hline \multicolumn{5}{|l|}{ Post-migration characteristics } \\
\hline Age & $\begin{array}{l}-0.037 \\
(0.09)\end{array}$ & $\begin{array}{l}-0.055 \\
(0.13)\end{array}$ & $\begin{array}{l}-0.117 \\
(0.12)\end{array}$ & $\begin{array}{c}0.685^{*} \\
(0.24)\end{array}$ \\
\hline Age squared & $\begin{array}{c}0.001 \\
(0.002)\end{array}$ & $\begin{array}{c}0.002 \\
(0.003)\end{array}$ & $\begin{array}{c}0.003 \\
(0.003)\end{array}$ & $\begin{array}{c}-0.016 * \\
(0.01)\end{array}$ \\
\hline Age cubic & $\begin{array}{c}-4.16 \mathrm{E}-06 \\
(1.80 \mathrm{E}-05)\end{array}$ & $\begin{array}{c}-1.570 \mathrm{E}-05 \\
(2.68 \mathrm{E}-05)\end{array}$ & $\begin{array}{c}-1.880 \mathrm{E}-05 \\
(2.03 \mathrm{E}-05)\end{array}$ & $\begin{array}{c}0.0001^{*} \\
(4.40 \mathrm{E}-05)\end{array}$ \\
\hline No degree in Germany & $\begin{array}{c}-0.287 \\
(0.19)\end{array}$ & $\begin{array}{c}-0.320 \\
(0.21)\end{array}$ & $\begin{array}{l}0.165 \\
(0.16)\end{array}$ & $\begin{array}{l}0.295 \\
(0.22)\end{array}$ \\
\hline Higher degree in Germany & $\begin{array}{l}-0.026 \\
(0.11)\end{array}$ & $\begin{array}{l}0.228 \\
(0.14)\end{array}$ & $\begin{array}{l}-0.162 \\
(0.11)\end{array}$ & $\begin{array}{l}-0.155 \\
(0.18)\end{array}$ \\
\hline University degree in Germany & $\begin{array}{l}0.039 \\
(0.14)\end{array}$ & $\begin{array}{l}0.138 \\
(0.18)\end{array}$ & $\begin{array}{c}-0.444^{*} \\
(0.19)\end{array}$ & $\begin{array}{l}0.214 \\
(0.24)\end{array}$ \\
\hline Hours worked & $\begin{array}{l}-0.002 \\
(0.004)\end{array}$ & $\begin{array}{l}0.0005 \\
(0.005)\end{array}$ & $\begin{array}{c}0.004 \\
(0.005)\end{array}$ & $\begin{array}{l}-0.006 \\
(0.01)\end{array}$ \\
\hline Number of observations & 406 & 406 & 406 & 406 \\
\hline Log Likelihood & -553.316 & -542.133 & -614.481 & -435.285 \\
\hline Pseudo- $\mathrm{R}^{2}$ & 0.024 & 0.071 & 0.075 & 0.034 \\
\hline
\end{tabular}

Note: The reference group consists of non-religious Turkish men, with no education in home country and primary or lower secondary education in Germany; Robust standard errors in parentheses; one-tailed t-test; * significant at 5\%. 
TABLE 4. Simulated Change in the Probability of Indicators of Economic Performance Caused by a Change of the Respective Ethnosizer Measure to its Maximum

\begin{tabular}{lccccc}
\hline \hline & \multicolumn{2}{l}{ Working probability } & \multicolumn{2}{c}{ Earnings } & \multirow{2}{*}{ Homeownership } \\
& Males & Females & Males & Females & \\
\cline { 2 - 6 } Integration & 0.079 & 0.199 & 1.573 & 3.651 & 0.261 \\
Assimilation & 0.122 & -0.011 & 1.194 & -0.024 & 0.348 \\
Separation & -0.064 & -0.081 & -1.410 & -1.043 & -0.171 \\
Marginalization & -0.204 & -0.078 & -2.556 & -3.438 & -0.082 \\
\hline
\end{tabular}

The entry in each cell should be understood as a change in the corresponding economic variable if the referenced measure of ethnic identity were at a maximum (i.e. equal to 5) and the remaining three measures were at a minimum (i.e. equal to 0 ) for all men and women respectively. In case of the working probability and the homeownership probability we investigate the resulting absolute change in the probability, comparing the state of full absorption with the average ethnosizer in the sample. In the case of earnings, numbers are the log differences of earnings of the hypothetical average individual in full absorption and the average individual in the sample (evaluated at sample means for all variables). 